\title{
VALIKULINE KOHUSTUS: EMAKEELNE KOOLIHARIDUS SÕDADEVAHELISES EESTIS
}

\author{
Triin Tark
}

1918. aasta lõpus, vahetult pärast Saksa okupatsioonivägede lahkumist ja Vabadussõja algust, kehtestas Eesti Vabariigi Ajutine Valitsus riigi edasist hariduskorraldust puudutanud määruse, mille järgi tuli kõik Eesti alal asunud koolid ümber kujundada vastavalt õpilaste emakeelele. ${ }^{1}$ Kiirkorras vastu võetud õigusakt sätestas pealtnäha igaühe õiguse emakeelsele haridusele, mis oli kooskõlas ajastu liberaalsete väärtustega. Hilisemate haridusvaldkonnas toimunud arengute ja kooliseaduste valguses omandab see määrus aga mõnevõrra teistsuguse tähenduse. Selle õigusakti vastuvõtmisega pani Ajutine Valitsus varakult aluse hoopis emakeelse hariduse kohustuslikkusele. Et viimast peeti vajalikuks sel moel selgesõnaliselt rõhutada, näitab ilmekalt, et emakeelses koolis käimine ei olnud iseseisvunud Eestis esialgu mingi enesestmõistetav nähtus.

Koolide õppekeele ja emakeelse hariduse küsimus ei ole sõdadevahelise perioodi hariduskorraldust puudutavates uurimustes üldjuhul omaette tähelepanu keskmes olnud. Haridusajaloo üldkäsitlustes on õppekeele temaatika jäänud tavaliselt täielikult tagaplaanile või on seda mainitud vaid põgusalt. Nõnda ei ole see teema pälvinud kaugeltki sarnast tähelepanu kui näiteks usuõpetuse ümber toimunud poleemika või kooliuuendusliikumise küsimused. ${ }^{2}$ Erandlikum on Tallinna 2o. sajandi hariduselu üldkäsitlus, mis pöörab õpilaste rahvuse temaatikale küllap enam tähelepanu seetõttu, et suuremates linnades, kus elas kõrvuti mitmeid rahvusgruppe, kerkis koolide õppekeele ja õpilaste rahvuse küsimus esile sagedamini kui

\footnotetext{
1 “Eesti Ajutise Valitsuse ajutised määrused koolide kohta, 02.12.1918”, Riigi Teataja, 5, 07.12.1918, 3-4.

2 Valik uurimusi, mis sõdadevahelise iseseisvusperioodi hariduselu käsitlevad: Ferdinand Eisen, Kooliuuenduse liikumisest Eestis 1918-1940 (Tallinn: Haridustöötajate Koolituskeskus, 1995); Lea Metsis, Eesti külakoolist kuueklassilise algkoolini (Tallinn: L. Metsis, 1995); Väino Sirk, "Haridus ja õpetajaskond Eestis omariikluse loomise aastatel (1917-1920. aastate algus)", Acta Historica Tallinnensia, 3 (1999), 130-155 (143-145); Lembit Andresen, Eesti rahvakooli ja pedagoogika ajalugu. IV. Iseseisvusaeg 1918-1940 (Tallinn: Avita, 2007); Väino Sirk, Veronika Varik, Eesti hariduse 100 aastat (Tallinn: Post Factum, 2018).
} 
Eestis keskmiselt. ${ }^{3}$ Kõige enam on rahvusküsimusele ja koolide õppekeelele tähelepanu pööranud aga Kari Alenius, kes on just neist aspektidest lähtudes käsitlenud Eesti koolikorralduse reforme 1920. aastate alguses. Ehkki tema 2007. aastal ilmunud artikkel piirdub iseseisvuse algusaastatega, on ometi tegemist pea ainsa uurimusega, mis juhib tähelepanu sellele, kuivõrd oli emakeelne koolikorraldus mõjutatud riigi rahvuspoliitikast. Ühtlasi tõstab Alenius esile, et poliitikud ja ametnikud püüdsid hariduspoliitikat suunates lähtuda arusaadavalt eelkõige eestlaste kui riigi põhirahvuse huvidest. Põhi- ja vähemusrahvuste huvide vastandumine tõi aga kaasa Ida- ja Kesk-Euroopa uutele riikidele iseloomuliku "dihhotoomia": vähemusrahvuste õigusi polnud võimalik täiel määral tagada, seadmata ohtu põhirahvuse ja seega ka riigi huvisid. ${ }^{4}$

Alenius näitab oma artiklis küll ilmekalt, et ühiskonna reaktsioon kohustusliku emakeelse hariduse sisseviimisele ei olnud ühemõtteliselt heakskiitev ega riigivõimu tegevus alati järjekindel, ent seni pole ilmunud uurimusi, mis käsitleksid riigi algusaastatel fikseeritud põhimõtte tagajärgi pikemas perspektiivis. Seetõttu analüüsitakse siinses artiklis ühiskonna kohanemist emakeelse haridussüsteemiga ning riigivõimu tegevust ühes järelevalvega emakeelse hariduse tagamisel. Keskmes on avalikkuses ja poliitikute seas levinud ideaal ning ühtaegu hariduspoliitika põhipostulaat, mille järgi eesti lapsed pidid igal juhul käima eestikeelses koolis. Ühtlasi käsitletakse vähemusrahvuste emakeelse hariduse problemaatikat - kas ja kui oluliseks pidas riik vähemusrahvustele emakeelsete koolide tagamist näiliselt üldise emakeelse haridussüsteemi taustal. Selle probleemideringi analüüsimiseks kasutatakse koolikorraldust puudutavaid õigusakte, nende ettevalmistamise ja vastuvõtmisega seotud dokumentatsiooni, ajakirjanduses ilmunud tekste, statistilisi andmeid ning koolide õppekeele problemaatikaga seotud mitmesugust arhiiviainest.

\section{Hariduspoliitika kujunemise eellugu}

Eesti hariduspoliitika kujunemist mõjutas olulisel määral asjaolu, et iseseisvuseelsel ajal ei olnud võimalik eesti keeles omandada mingisugust arvestatavat ega edasiõppimist võimaldavat üldharidust. Lisaks oli Venemaa keisririigi haridussüsteem killustunud ega taganud loomulikku madalamalt

\footnotetext{
3 Mare Torm, "Koolielu korraldamine", Tallinna hariduselu 1918-2010: üldharidus ja hariduskorraldus, koost Veronika Varik (Tallinn: Tallinna Haridusamet, 2012), 73-78. 4 Kari Alenius, “"Away with German and Russian influence!” Ethno-politcal considerations in the reorganisation of the Estonian school system in the early 1920s", Zeitschrift für Ostmitteleuropa-Forschung, 3 (56) (2007), 347-363.
} 
õppetasemelt kõrgemale liikumist, mis omakorda piiras talurahvakoolide õpilaste edasiõppimisvõimalusi. Selle tulemusena eelistasid mitmed eesti lapsevanemad saata oma lapsed juba varakult mainekatesse saksa- või venekeelsetesse koolidesse, et tagada neile hiljem paremad võimalused kõrghariduse omandamiseks. Kui sageli selliseid valikuid ette tuli ja kui paljud lapsevanemad seda endale lubada said, on ebaselge, ent juba ainuüksi ettekujutus sellest, et mõned lapsevanemad teadlikult võõrkeelseid koole eelistasid, mõjutas märkimisväärselt kujuneva haritlaskonna meeleolusid ja suunas edaspidi ka iseseisvunud Eesti hariduspoliitikat. ${ }^{5}$

Mitmed haritlased uskusid, et võõrkeelne haridus soodustab ümberrahvastamist ja on seega rahvuse püsimise seisukohalt ohtlik. Lisaks rõhutati, et vähemalt alghariduse võiksid õpilased omandada emakeeles. ${ }^{6} \mathrm{Nii}$ kujunes vahetult iseseisvuseelseks ajaks haritlaskonnas välja selge arusaam eestikeelse hariduse vajadusest. Selle ideaali taustal nägid haritlased võõrkeeltes hariduse omandamist esialgu veel paratamatusena. Samas oli loodud soodne pinnas tauniva suhtumise tekkele vanemate valikutesse niipea, kui üldine eestikeelne alg- ja keskharidus juba vähegi reaalse eesmärgina paistma hakkas. Õigupoolest tekkisid teatavad võimalused eestikeelse hariduse sisseseadmiseks juba veidi enne iseseisvumist, 1917. aasta kevade revolutsiooniliste sündmuste mõjul. Muutunud oludes seadsid mitmed haridusvaldkonna juhtfiguurid eesotsas Peeter Põlluga eesmärgiks tagada eestikeelne haridus kõigil astmetel, esialgu algharidusest kutsehariduseni, mille saavutamiseks astuti mitmeid samme juba sama aasta suvel. Septembris saadi Venemaa rahvahariduse ministrilt luba õpetada algkoolides kohalikes keeltes tingimusel, et säiliks ka vene keele õpetamine eraldi õppeainena. Keskkoolide muutmine eestikeelseks toimus aeglasemalt, ehkki 1917. aasta sügisel tehti ka sellega algust. ${ }^{7}$ Arutelusid peeti ja konkreetseid samme astutigi tollal just eestikeelset haridust silmas pidades, teiste Eesti alal elanud rahvuste emakeelne haridus eesti poliitikute prioriteetide hulka ei kuulunud, seda enam, et saksa- ja venekeelseid koole käsitleti ohuna ning ülejäänud rahvused olid liiga väiksearvulised, et poliitikute tähelepanu äratada.

On loomulik, et iseseisvuseelsel ajal kogunenud teadmised, arusaamad ja hoiakud hakkasid edaspidi kujundama ka iseseisva Eesti riigi hariduspoliitikat. Küllap oli juba väljakujunenud seisukohtade püsimises oma roll

\footnotetext{
5 Vrd Jüri Annusson, Wana ja uus kool (Tallinn: Vaba Maa, 1920), 9.

6 Vt nt Annusson, Wana ja uus kool, 5; Peeter Põld, "Rahvaharidus ja rahvakeel", Kasvatus ja Haridus, 1 (1) (1917), 15-23; Peeter Põld, "Rahvaharidus ja rahvakeel II", Kasvatus ja Haridus, 2 (1) (1917), 42-49.

7 Sirk, "Haridus ja õpetajaskond Eestis", 133-135.
} 
lapsevanemate eelistustel, mis olid sageli sama püsivad nagu hariduspoliitika põhialused. Vanemate eelistuste püsimisele aitasid ilmselt kaasa ilmasõja lõpuaastatel levima hakanud pessimistlikud sõnumid, et eesti rahvakoolid on katastroofi äärel ja kirjaoskamatus süveneb. ${ }^{8}$ Selliste arvamuste levikusse andis iroonilisel kombel oma panuse ka Eesti ala hariduspoliitikat kujundama asunud eestikeelne eliit, kelle jaoks oli esmatähtis uuenduste õigustamine, mistõttu ei pruukinud koolide tegelik olukord ilmtingimata nii kriitilises seisus olla, nagu arvukates seisukohavõttudes esile toodi. ${ }^{9}$ Küll aga ei ole haridusolude eriti süngetes toonides kujutamise taustal üllatav, et ka vahetult Eesti iseseisvumise eel leidus ühiskonnas hulk lapsevanemaid, kes võimalusel eelistasid eestikeelseid rahvakoole vältida. Pole põhjust eeldada, nagu oleksid vanemate valikud ja eelarvamused eestikeelsete koolide suhtes pelgalt omariikluse tekkega järsult muutunud. ${ }^{10}$

\section{Esimesed koolikorralduslikud õigusaktid}

30. novembril 1918 Riigi Teatajas ilmunud Ajutise Valitsuse deklaratsioonis riigielu edasisest korralda misest märgiti, et hariduspoliitika prioriteediks peab olema venestamise ja saksastamise katsete lõpetamine, mistõttu tuleb kõik koolid "rahvuslisele alusele seada". ${ }^{11}$ Järgnevalt asuti seda põhimõtet ka kiirkorras ellu viima. Nagu sissejuhatuses märgitud, sõnastati emakeelse hariduse kohustuslikkus esmakordselt Ajutise Valitsuse 1918. aasta lõpus välja antud hariduskorralduslikus määruses, mis kohustas koolivalitsusi korraldama koolid ümber vastavalt õpilaste emakeelele. Seega tuli suure vähemusrahvuste osakaaluga piirkondades tagada vastavates keeltes koolid või paralleelklassid. ${ }^{12}$ Veelgi selgemalt kui määruses, oli kohustus omandada algharidus emakeeles esile toodud hilisemas lisaselgituses. Sellest ilmneb, kui kategooriliselt ja kindlalt oli emakeelse hariduse põhimõte poliitikute ja haridusministeeriumi ametnike seas juurdunud. ${ }^{13}$ Koolide

\footnotetext{
$8 \quad$ Vrd Sirk, "Haridus ja õpetajaskond Eestis", 132, 135.

9 Mitmeid teemakohaseid kirjutisi ilmus näiteks 1917. aastal välja antud ajakirjas Kasvatus ja Haridus.

10 Kuigi leidus ka vanemaid, kes Eesti iseseisvumise järel lapsed prestiižsest Toomkoolist eestikeelsetesse koolidesse üle viisid, pole siiski põhjust selles väga levinud ja üle-eestilist suundumust näha. Vrd Olev Liivik, “Toomkool 1906-1939”, Kaheksanda sajandi lävepakul: Tallinna Toomkool 1319-2019, koost Priit Rohtmets (Tallinn: Tallinna Toomkool, 2019), 151-195 (164).

11 "Ajutise Valitsuse deklaratsion [sic]", Riigi Teataja, 3, 30.11.1918, 8.

12 "Eesti Ajutise Valitsuse ajutised määrused koolide kohta".

13 “Ajutise Valitsuse 2. detsembri 1918. a. määruste läbiviimisest, 06.12.1918”, Kasvatus: Ametlik osa, 2 (1) (1919), 25.
} 
õppekeelt puudutavatest põhimõtetest ei loobutud ka edasiste kooliseaduste vastuvõtmisel.

Emakeelse hariduse kui kohustuse fikseerimine ei tähendanud siiski, nagu poliitikud poleks sellest samal ajal mõelnud ka kui õigusest. Kahe sisult vastandliku arusaama läbipõimumine peegeldub 1919. aastal vastu võetud ajutises põhiseaduses, milles vastupidiselt varasematele ja hilisematele õigusaktidele toonitati õigust emakeelsele haridusele ja kohustuse mõistet ei kasutatud. Samas näitab ajutise põhiseaduse eelnõu arutelu, et üha selgemalt hakati tajuma, et emakeelset haridust pole võimalik täiel määral tagada. Tõstatus küsimus, kui palju peaks olema mingist rahvusest õpilasi, et neile omakeelne klass avada. ${ }^{14} \mathrm{Näib}$, et mida enam mööndi emakeelse hariduse tagamisega kaasnevaid praktilisi raskusi, seda enam hakkas lahknema ka arusaam põhi- ja vähemusrahvuste võrdsest õigusest emakeelsele haridusele ning kohustusest seda õigust kasutada.

Ajutise põhiseaduse sõnastus jäi igal juhul erandlikuks ega andnud tooni ka järgnenud avalike algkoolide seaduse eelnõu lugemisel. 1920. aasta kevadel Asutavas Kogus vastu võetud seaduse eelnõu üle toimunud arutelud näitasid, et emakeelse hariduse kohustuslikkuse idee oli poliitikute seas jätkuvalt tugevalt juurdunud ja seda ei püüdnud vaidlustada ükski poliitiline jõud. Emakeelse hariduse kehtestamist pidasid ühemõtteliselt vajalikuks ka vähemusrahvuste esindajad, kes mõistagi olid huvitatud, et nendegi koolidel jätkuvalt eluõigus oleks. ${ }^{15}$ Ei saa välistada, et kategoorilise kohustuse kahtluse alla seadmine võinuks kaasa tuua ka kahtlused vähemusrahvustele emakeelse hariduse tagamise vajalikkuses, milleni jõudmist poleks soovinud ei sakslaste, rootslaste ega venelaste esindajad. Ka juhul, kui sellise stsenaariumi rakendumist polnud põhjust kahtlustada, võinuks kooli õppekeele vaba valiku korral hakata vähemusrahvustest vanemad eelistama hoopis riigikeelseid või mõne teise vähemuse koole, nii nagu see hiljem juhtus näiteks paljude (ingeri-)soomlastega, kes oma emakeelse hariduse nimel ise aktiivselt ei võidelnud ja eelistasid kas eestivõi venekeelseid koole. ${ }^{16}$

\footnotetext{
14 "Eesti vabariigi valitsemise ajutine kord, 04.06.1919", Riigi Teataja, 44, 09.07.1919, 346; Hannes Vallikivi, "Kodanikuõiguste peatükk Eesti 1919. aasta ajutises põhiseaduses", Ajalooline Ajakiri, 3/4 (2019), 293-330 (316-318).

15 Õppekeele küsimust puudutanud istungite protokollid: Asutava Kogu 3. istungjärk, protokoll nr 103, 06.02.1920; Asutava Kogu 3. istungjärk, protokoll nr 106, 13.02.1920; Asutava Kogu 3. istungjärk, protokoll nr 107, 17.02.1920; Asutava Kogu 3. istungjärk, protokoll nr 108, 20.02.1920; Asutava Kogu 4. istungjärk, protokoll nr 127, 04.05.1920.

16 Alenius, “Away with Russian and German Influence!", 356, 359-362.
} 
Kõige kirgikütvamaks vaidluspunktiks algkoolide seaduse eelnõu lugemisel kujunes küsimus, kellel ja mille alusel peaks olema õigus õpilaste emakeele resp rahvuse üle otsustada. Vastavad arutelud toovad ilmekalt esile, millist eesmärki eesti poliitikud emakeelsel haridussüsteemil nägid. Hilisema haridusministri Aleksander Veidermanni sõnavõttude järgi tuli vältida kooli muutumist “ümberrahvastumise abinõuks" ja seetõttu ei saanud jätta vanematele vabadust oma laste rahvuse üle otsustada, ehkki tegemist oleks ka tema nägemuses olnud ideaalvariandiga. Vanemate õigust oma laste rahvuse üle otsustada oleks seevastu soovinud näiteks sakslaste esindaja Max Bock. Küsimus, mil moel ja kelle poolt õpilaste rahvust määrata tuleks, jäigi Asutavas Kogus lõpuks vastuseta. ${ }^{17}$

Avalike algkoolide seadus vastuvõetud kujul kordas sisuliselt Ajutise Valitsuse määrusesse kirja pandud põhimõtteid. Õpilaste emakeelt arvestati nende rahvuse järgi, mis tegelikkuses tähendas, et kui õpilase ametlikult fikseeritud rahvus ei olnud vastavuses perekonna koduse keelega, ei pruukinud ta seadusest lähtudes oma "emakeelt" osata. Rahvust omakorda tuli arvestada vanemate rahvuse järgi, kusjuures segaperede vanemad võisid lapse rahvuse üle otsustada omavahelisel kokkuleppel, aga mõistagi vastavalt kummagi vanema rahvusele. Juhul, kui ópilase rahvusele resp emakeelele vastavat kooli elukoha läheduses ei leidunud, võisid vanemad valida endale meelepärase läheduses asunud kooli olenemata õppekeelest. Ehkki üldiselt olid kõik algkoolide õpilased kohustatud õppima oma emakeelses koolis, oli põhimõtteliselt võimalik mitte ainult viimase puudumisel, vaid ka kohaliku koolivalitsuse eriloa alusel õppida mõnes muus koolis. ${ }^{18}$ Kuna kõigile vähemusrahvustele ja kõigis piirkondades polnud võimalik ega mõistlik emakeelset haridust tagada, oli ilmne, et täiel määral sai emakeelse hariduse kohustuslikkus kehtima hakata ainult eestlastest õpilastele.

1922. aastal võeti vastu ka keskkoolide seadus, mis üldjoontes rõhutas samuti emakeelse hariduse kohustuslikkust. Seaduse ettevalmistamisel tekitas mõningast elevust haridusministeeriumi ja Riigikogu hariduskomisjoni esimehe Jüri Annussoni eelnõude lahknevus, mis koolide õppekeelt puudutas nii palju, et Annussoni eelnõu järgi pidanuks keskkoolid analoogselt algkoolidele olema kõigile rahvustele ühtmoodi emakeelsed, samas kui haridusministeeriumi eelnõu järgi võinuks riigikeelsetes koolides õppida kõigist rahvustest õpilased. ${ }^{19}$ Lõpuks võimaldaski keskkoolide seadus vastavalt haridusministeeriumi eelnõule vähemusrahvustest õpilastel

\footnotetext{
$17 \quad$ Asutava Kogu 3. istungjärk, protokoll nr 107, 17.02.1920, vg 382-383.

18 "Avalikkude algkoolide seadus, 07.05.1920", Riigi Teataja, 75/76, 22.05.1920, 593-594.

19 Ernst Martinson, "Avalikkude üldharidusliste keskkoolide seaduse eelnõu", Kasvatus, 3 (20) (1921), 309-312 (311).
} 
käia soovi korral ka riigikeelses keskkoolis ilma eriluba taotlemata. ${ }^{20}$ Selle erandi puhul pidi olema eelkõige tegemist praktilise, mitte niivõrd ideelise kaalutlusega, kuna keskkoolide võrk oli hõredam ja vähemusrahvuste keeltes keskkoole leidus märksa vähem kui algkoole. ${ }^{21}$ Annussoni eelnõu läbiminek oleks seega tähendanud, et vähemusrahvustest õpilaste edasiõppimise võimalused oleksid märgatavalt ahenenud. Ent samal ajal, kui seadus võimaldas vähemusrahvustel õppida ka riigikeelsetes keskkoolides, püsis jätkuvalt selge põhimõte, et eestlased on kohustatud ka teises kooliastmes õppima eestikeelses koolis.

Kari Alenius on ilmekalt näidanud, et esimeste koolikorralduslike õigusaktidega tagati vähemusrahvustele suurem vabadus koolivalikul kui eestlastele. ${ }^{22}$ Pealtnäha paradoksaalsena mõjuv asjaolu tekitas tegelikult võimaluse haridussüsteemi abil vähemusrahvusi eestlaste sekka sulandada. Avalikult poliitikud vähemusrahvuste assimileerimisest siiski ei rääkinud ja küllap enamikul neist sellist soovi polnudki. Igal juhul mõjunuks taolised sõnavõtud silmakirjalikuna, kuivõrd samal ajal räägiti järjepidevalt vajadusest takistada eesti laste ümberrahvastamist.

\section{Vastuolulised koolieelistused}

Ehkki eestlaste "ümberrahvastumise" oht oli olukorras, kus riigi elanikkonnast ligi 90\% moodustasid eestlased, pigem marginaalne, ilmnes aja jooksul siiski, et avalike algkoolide seaduse elluviimine ei osutu nii lihtsaks, kui algselt oli loodetud. Juba esimeste iseseisvusaastatega sai selgeks, et Asutava Kogu liikmete sõnavõtud algkoolide seaduseelnõu aruteludel seoses õpilaste rahvuse määramisega ei olnud täiesti alusetud. Tõepoolest ei olnud seadusega kehtestatud emakeelse hariduse kohustuslikkus piisavaks hoovaks kõigi eestlasteks arvatud laste eestikeelsetesse koolidesse suunamiseks, ent näib, et suuremaks ja kestvamaks takistuseks osutusid mitte niivõrd saksa- ja venekeelsete koolide aktiivsed sammud oma õpilaste arvu säilitamiseks, vaid lapsevanemate eneste eelistused. ${ }^{23}$ Seejuures puudutasid vanemate seadusega sätestatust lahknevad valikud enim just algkoole, mistõttu analüüsitaksegi järgnevalt esimest kooliastet puudutavaid andmeid.

\footnotetext{
20 “Avalikkude keskkoolide seadus, 07.12.1922", Riigi Teataja, 155/156, 16.12.1922, 749.

$21 \quad$ Vrd nt RA, ERA.1108.1.154, 1. 373: Rahvahariduse statistika nr 50.

22 Alenius, "Away with German and Russian Influence!", 349.

23 Sellele, et saksa- ja venekeelsed koolid olevat püüdnud 1919. aastal takistada õpilaste üleviimist eestikeelsetesse koolidesse, on viidanud Väino Sirk. Lapsevanemate rolli seevastu on esile tõstnud Kari Alenius. Vrd Sirk, "Haridus ja õpetajaskond Eestis", 141; Alenius, "Away with German and Russian Influence!", 351-355.
} 
Mitte-emakeelses koolis õppimiseks leidus õigupoolest mitmeid võimalusi. Üheks võimaluseks olid juba mainitud eriload, mida vastavalt algkoolide seadusele võisid väljastada kohalikud koolivalitsused. Teine võimalus oli muuta ühe vanema või lapse enda isikutunnistusel leidunud rahvusmärget, kuivõrd just see oli õpilaste emakeele määramise aluseks. ${ }^{24}$ Kolmas võimalus oli loota selle peale, et soovitud kooli pidaja või juhataja on valmis võtma riski ja vaatama eriloa nõudmisest mööda. Kõiki siinnimetatud olukordi tuli ette korduvalt, kuid otsesed andmed ühe või teise meetodi kasutamise leviku kohta on ebaühtlased. Siiski on võimalik õpilaste arvu, mitte-emakeelses koolis õppimise leviku ulatuse ning ametliku rahvuskuuluvuse muutusi puudutavate näitajate võrdlemisel täpsustada, millised meetodid olid levinumad ja kui ulatuslikuks võiks üldse pidada eestlaste õppimist mitte-emakeelsetes koolides.

Kõige kindlamalt on teada erilubade alusel mitte-emakeelses koolis õppinute arv, mis kajastub regulaarselt avaldatud statistilises andmestikus. Need andmed ilmusid alates õppeaastast 1922/23 Eesti Statistika kuukirjas. Seejuures on 1920. aastatele iseloomulik, et ajakirjas peeti vajalikuks esile tuua küll eestlastest õpilaste osakaalud vähemusrahvuste koolides, aga mitte vähemusrahvustest õpilaste osakaalu ja arve mõne teise vähemusrahvuse koolides (samuti ei ole esitatud vähemusrahvustest õpilaste osakaalu eestikeelsetes koolides, mida on aga võimalik olemasolevate andmete põhjal välja arvutada). Ühtlasi jõudsid statistika kuukirja veergudele üldjuhul ainult need vähemusrahvuste koolid, milles eestlastest õpilasi leidus kõige enam. Riigi hariduspoliitilisi prioriteete peegeldavad sellised andmekogumise valikud päris hästi.

Joonistel 1 ja 2 on esitatud statistika kuukirja andmestiku põhjal ülevaade mitte-emakeelsetes koolides õppinud eestlaste suht- ja absoluutarvude muutumise kohta aastate lõikes. Eestlaste suhtarvud vähemusrahvuste koolides olid esitatud pidevalt ja toovad seega aastate jooksul toimunud muutused hästi esile. Samas on absoluutarvude puudumisel kujunev pilt mõnevõrra moonutatud. Näiteks võib suhtarvude põhjal jääda ekslik mulje, nagu oleks saksakeelsetes koolides õppinud vaid mõnevõrra vähem eestlasi kui venekeelsetes koolides. Võttes aga arvesse, et venekeelsete koolide õpilaste arv kokku oli kordades kõrgem kui saksakeelsetes koolides, oli erinevus tegelikult enam kui kümnekordne. Osaliselt tuleb see välja jooniselt 2, millel on kajastatud eestlaste absoluutarvud vene- ja saksakeelsetes

$24 \quad$ Alates 1919. aasta sügisest väljastatud isikutunnistused sisaldasid teiste andmete seas ka märget dokumendi omaniku rahvuse kohta, mis sai aluseks rahvuse määramisele mitmesugustes olukordades, kus rahvus omas ametlikku tähtsust, muu hulgas ka seoses kooli õppekeelega. 


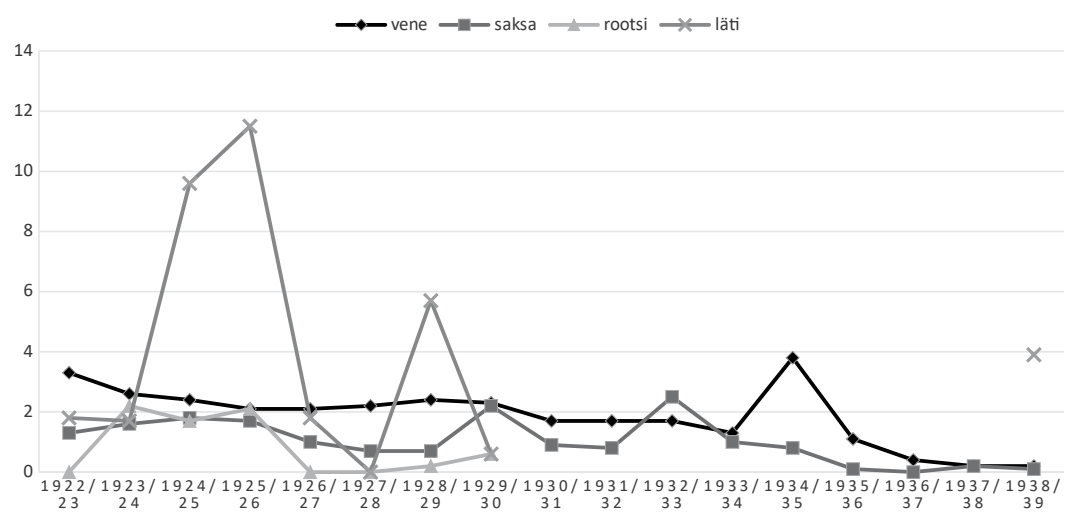

Joonis 1. Eestlaste osakaal vene, saksa, rootsi ja läti õppekeeltega koolides. Eesti Statistika, 43 (1925); 60 (1926); 72 (1927); 79 (1928); 88 (1929); 99 (1930); 111 (1931); 123 (1932); 135 (1933); 147 (1934); 157 (1934); 169 (1935); 181 (1936); 193 (1937); 205 (1938); 217 (1939)

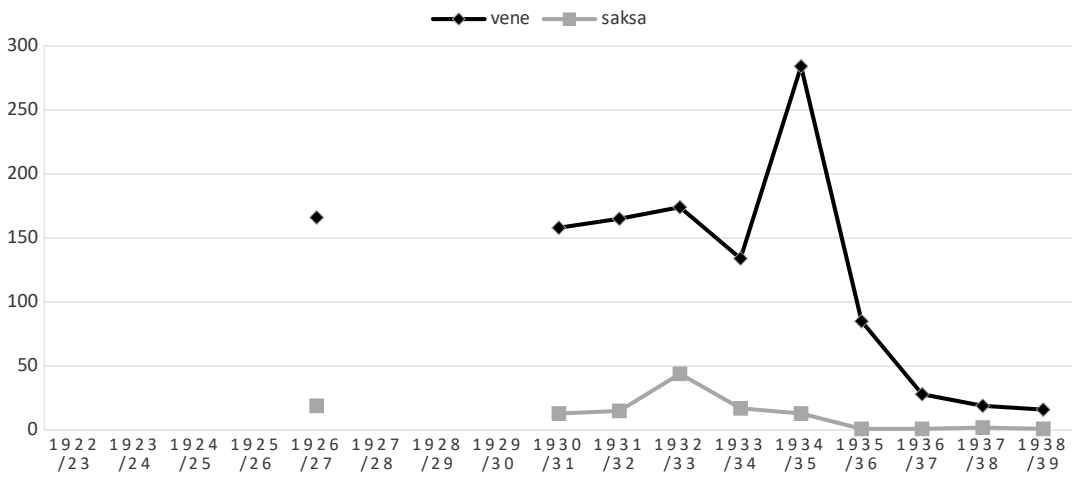

Joonis 2. Eestlaste arv vene- ja saksakeelsetes koolides. Eesti Statistika, 79 (1928); 123 (1932); 135 (1933); 147 (1934); 157 (1934); 169 (1935); 181 (1936); 193 (1937); 205 (1938); 217 (1939)

koolides õppeaastal 1926/27 ning pärast mõneaastast pausi järjepidevamalt 1930. aastatel. Eestlaste arv teiste vähemusrahvuste, eelkõige rootsi ja läti õppekeelega koolides oli marginaalne, ehkki aastati võis olukord erineda. Vabariigi algusaastatel oli nimelt mõnel aastal eestlaste osakaal läti- ja rootsikeelsetes koolides anomaalselt suur, ent hiljem siiski langes ja stabiliseerus ning alates 1930/31. õppeaastast ei peetud seda vajalikuks statistikas eraldi esile tuuagi. Segarahvastikuga piirkondades oli selline esialgu ebaühtlane 


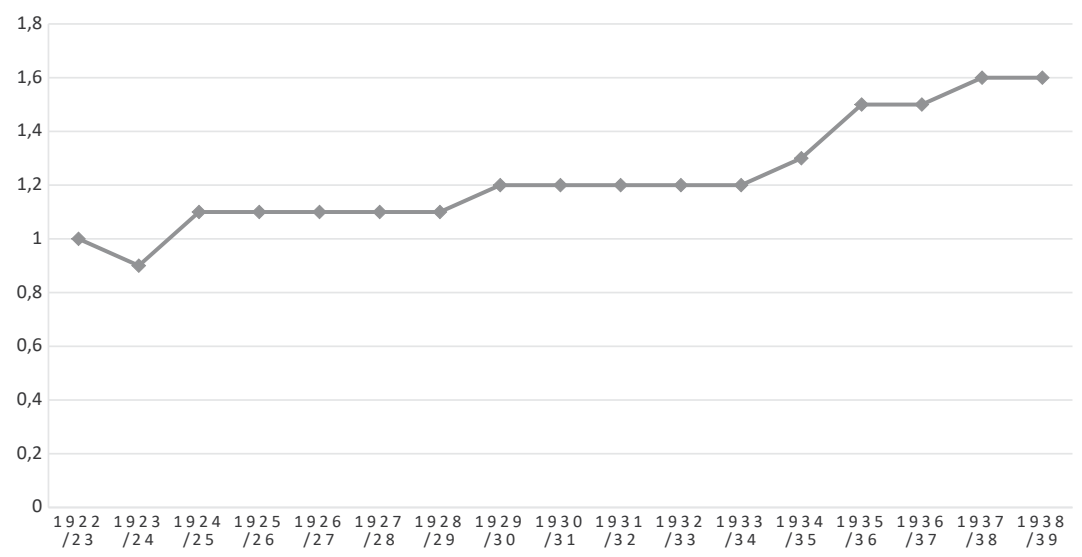

Joonis 3. Vähemusrahvustest õpilaste osakaal eestikeelsetes koolides. Eesti Statistika, 43 (1925); 60 (1926); 72 (1927); 79 (1928); 88 (1929); 99 (1930); 111 (1931); 123 (1932); 135 (1933); 147 (1934); 157 (1934); 169 (1935); 181 (1936); 193 (1937); 205 (1938); 217 (1939)

tulemus ka mõneti paratamatu. ${ }^{25}$ Emakeelset haridust ja mitte-emakeelsetes koolides õppimist puudutanud diskussioonides ja edasistes arengutes läti- ja rootsikeelsed koolid igal juhul märkimisväärset rolli ei mänginud.

Saksa- ja venekeelsetes koolides õppinud eestlaste osakaal oli aastate lõikes suhteliselt stabiilne. Samuti ei kasvanud 1920. aastate jooksul märkimisväärselt vähemusrahvustest õpilaste osakaal eestikeelsetes koolides, nagu nähtub jooniselt 3 . See ei tähenda, et vähemusrahvustest õpilased üldjuhul oma emakeelses koolis käisid, vanemad võisid tahtlikult või olude sunnil valida ka mõne teise vähemusrahvuse kooli. Vähemusrahvuste esindajate koolieelistused haridusametnikele üldjuhul muret ei valmistanud, ja nagu visalt $1 \%$ juures püsinud vähemusrahvuste osakaal eestikeelsetes koolides vihjab, vähemasti esialgu ei püütud neid väga ka riigikeelsetesse koolidesse suunata.

Statistiliste andmete järgi oli eestlaste arv vähemusrahvuste koolides võrdlemisi tagasihoidlik. See näitab, et koolivalitsused ei väljastanud erilubasid just kergekäeliselt (arvatavasti haridusministeeriumi survel) ja nii ei olnud vanematel, kes olid isikutunnistuste järgi eestlased, aga eelistanuks eri põhjustel mõne vähemusrahvuse kooli, kuigi lihtne oma eesmärki ainult eriloa abil saavutada. Statistika põhjal paistab ka, et eriloa saamine oli tõenäolisem venekeelses koolis õppimiseks, kuna sellise loa vajadust

25 Valga lätikeelsete koolide kohta vt nt Vahur Ilumets, "Valga koolid aastatel 19201940" (magistritöö, Tartu Ülikool, 2015), 65-68. 
oli vähemasti Venemaalt opteerunutel ka võrdlemisi lihtne põhjendada: venekeelses keskkonnas kasvanud laps ei pruukinud olla esialgu võimeline eestikeelses koolis õppima. ${ }^{26}$ Kas optantide koolieelistuse põhjuseks oli alati puudulik eesti keele oskus või esines ka muid kaalutlusi, on aga omaette küsimus, mis väljub siinse uurimuse raamidest. Kindlasti ei ole pelgalt statistika põhjal võimalik väita, et just saksakeelsetes algkoolides õppis märkimisväärselt palju eestlasi, ehkki poliitikute, haridusametnike ja avalikkuse silmis oli probleemiks just see nähtus.

Arvatavasti olid haridusametnikud endiselt ümberrahvastumist ohuks pidades eriti tõrksad väljastama erilubasid saksakeelsetes koolides õppimiseks, lisaks ei olnud sellise loa taotlemist alati ka kuigi lihtne põhjendada. Niisiis oli saksakeelseid koole eelistanud perekondade ühel abikaasadest mõttekam taotleda hoopis isikutunnistuse rahvusmärke muutmist. 1930. aastal võeti kasutusele ka uued, ilma rahvusmärketa isikutunnistuste blanketid, mille järel muutus märksa lihtsamaks enda ja oma laste nimede Saksa Kultuuromavalitsuse ${ }^{27}$ rahvusnimekirja kandmine, mis omakorda andis automaatselt õiguse saksakeelse kooli valikuks. On teada, et tõepoolest leidus inimesi, kes koolieelistuse tõttu soovisid isikutunnistuse rahvusmärget muuta või Saksa Kultuuromavalitsuse rahvusnimekirja pääseda. Kui palju neid täpselt oli, jääb aga selgusetuks, sest ehkki leiduvad küllaltki täpsed andmed nende kohta, kes olid algse isikutunnistuse järgi "eestlased", ent soovisid saada "sakslaseks", ei ole enamasti võimalik pelgalt taotluste põhjal tuvastada, mis oli selle soovi põhjuseks. Ajavahemikus 1921-24 esitati teadaolevalt natuke üle 200 rahvusmärke muutmise taotluse ja üldjuhul neist põhjus ei ilmne. Vaid üksikutel juhtudel on taotluses nimetatud, et rahvust soovitakse muuta kooli tõttu. 1925. aastal kasvas rahvusmärget muuta soovinute hulk mitmekordseks seoses sooviga astuda Saksa Kultuuromavalitsuse rahvusnimekirja, mis omakorda võis paljudel juhtudel tuleneda koolieelistusest. Ühtekokku oli kuni 1930. aastani "sakslaseks" saada soovinud "eestlasi" ligikaudu 100o. ${ }^{28}$ Isegi kui

\footnotetext{
26 Venemaalt Tartu rahulepingu alusel Eesti kodakondsusse opteerunud ja Eestisse tagasirännanud inimesi peeti sageli vaikimisi eestlasteks, mis kajastus ka nende hilisemates isikutunnistustes. See tähendas omakorda, et nende lapsed olid riigi silmis eestlased, kes ei pruukinud oma emakeelt osata.

27 Saksa Kultuuromavalitsus rajati 1925. aasta sügisel sama aasta alguses vastu võetud vähemusrahvuste kultuuromavalitsuse seaduse alusel. Kultuuriautonoomia ja Saksa Kultuuromavalitsuse kohta vt lähemalt nt Kaido Laurits, Saksa kultuuromavalitsus Eesti Vabariigis 1925-1940: monograafia ja allikad (Tallinn: Rahvusarhiiv, 2008).

28 Mainitud arvud on tuletatud Rahvusarhiivis siseministeeriumi fondis RA, ERA.14 ja politseitalituse fondis RA, ERA.1 leiduvatest isikutunnistusel rahvusmärke muutmise taotlustest.
} 


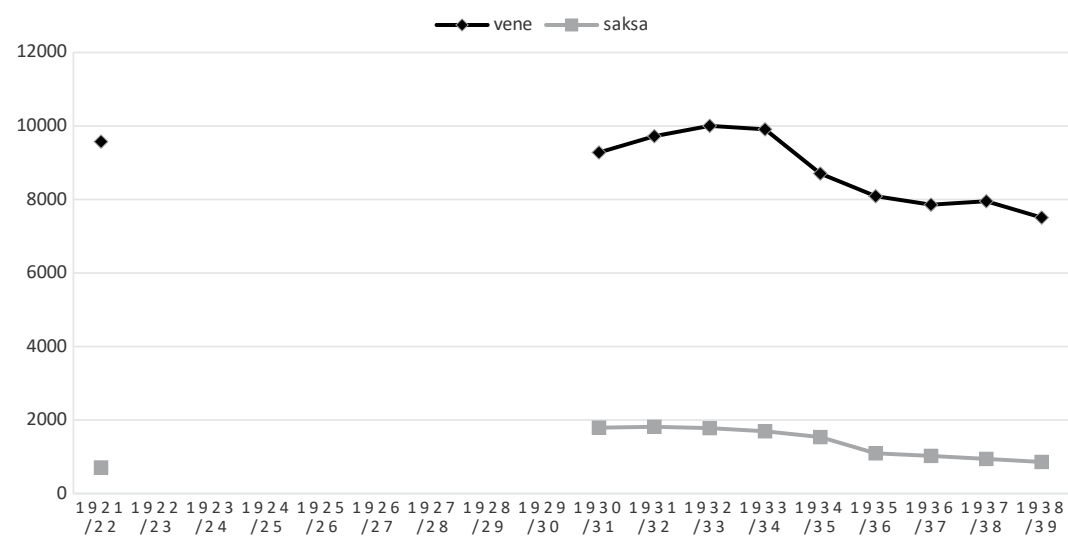

Joonis 4. Vene- ja saksakeelsete koolide õpilaste arv. Eesti Statistika, 13 (1923); 123 (1932); 135 (1933); 147 (1934); 157 (1934); 169 (1935); 181 (1936); 193 (1937); 205 (1938); 217 (1939)

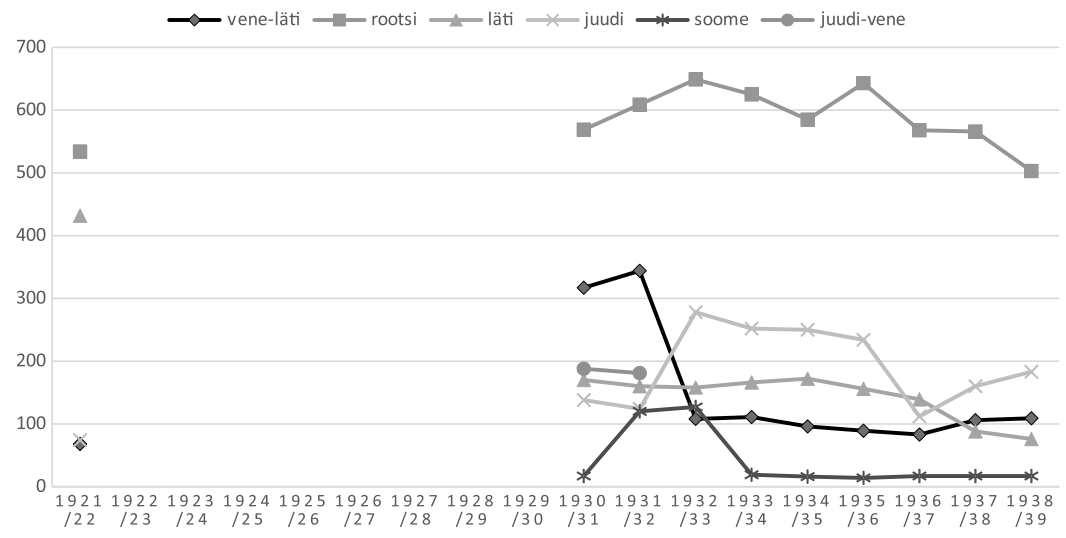

Joonis 5. Väiksearvuliste vähemusrahvuste koolide õpilaste arv. Eesti Statistika, 13 (1923); 123 (1932); 135 (1933); 147 (1934); 157 (1934); 169 (1935); 181 (1936); 193 (1937); 205 (1938); 217 (1939)

eeldada hüpoteetiliselt, et kõigi nende ja lisaks alates 1930. aastast Saksa Kultuuromavalitsusse astunud inimeste motiiviks oli koolivalik, siis võiks rääkida keskmiselt natuke enam kui 100 inimesest aastas, kes oma rahvuskuuluvust koolieelistuse tõttu "moonutasid". Tegelikkuses pidi neid olema aga märksa vähem, sest on teada, et mitte kõigil juhtudel ei olnud põhjuseks kool, paljudel rahvusmärke muutjatel nimelt polnudki kooliealisi või 
kooliealiseks saavaid lapsi. Arvestades samas, et saksakeelsete algkoolide ópilaste koguarv ei küündinud üle 2000 (joonis 4), on ka kahekohaline koolieelistuse tõttu rahvust muutnute arv aastas märkimisväärne.

Isikutunnistuse rahvusmärgete muutmist ja kultuuromavalitsuse rahvusnimekirja püüdlemist iseloomustavate näitajate kõrval leidub veel mõningaid silmatorkavalt anomaalseid andmeid, mille üheks põhjuseks võis olla saksakeelsete koolide populaarsus. Näiteks 1918/19. õppeaastal oli haridusministeeriumi andmetel algkoolide õpilaste hulgas sakslasi 297, venelasi 4491, rootslasi 397, soomlasi 9, lätlasi 899, juute 126 ja ülejäänud vähemusrahvustest õpilasi kokku $60 .^{29}$ Kui lisada siia võrdluseks hilisemast ajast pärinevad andmed vähemusrahvuste koolide õpilaste arvu kohta (joonised 4 ja 5), ilmnevad kõnekad erinevused.

Venekeelsete koolide õpilaste arv püsis edaspidi stabiilselt 10 ooo piirimail, olles seega ligikaudu kaks korda kõrgem kui 1919. aastal fikseeritud venelastest õpilaste arv. Seda erinevust saab selgitada nii hiljem Tartu rahulepingu alusel lisandunud territooriumiga kui ka optantide suure osakaaluga elanikkonnas. Riigipiiri nihutamised võisid olla ka lätlaste arvu ja hilisema lätikeelsetes koolides õppinute mitmekordse erinevuse põhjuseks. Seevastu 1919. aastal fikseeritud sakslastest õpilaste arv mõjub esmapilgul seletamatult madalana. Mingis osas võib sellegi taga olla suure hulga sakslaste ajutine Eestist eemalviibimine, mis võib ehk osaliselt selgitada enam kui kahekordset kasvu napilt paari järgnenud aasta jooksul. Ent saksakeelsete koolide õpilaste arvu kasv ajavahemikus 1922-31 pidi mingil määral tulema ka teiste rahvuste arvelt, kuna sakslaste koguarv Eestis oli pidevas langustrendis ja sündimus madal. ${ }^{30}$ Sakslastest õpilaste väikest arvu 1919. aastal võis mõjutada seegi, et ametnike poolt ei pruugitud sakslastena kirja panna kõiki neid õpilasi, kelle perekonnad ise ennast sakslasteks pidasid, ent kelle esivanemaid ametnikud teadsid olevat eestlased.

Anomaalsena mõjuvad eelneva taustal ka 1922. ja 1934. aasta rahvaloenduse andmed. Esimese rahvaloenduse järgi elas Eestis 220 vanuserühma 0-9 kuulunud sakslast, seevastu 1934. aasta rahvaloendusel oli vanuserühma 10-14 kuulunuid 1077. Ehkki üldine sündimus 1920. aastate alguses Eestis mõneks ajaks veidi tõusis, ei saa seda erinevust seletada loomuliku iibega. ${ }^{31}$ Tõenäolisemalt oli teise rahvaloenduse ajal rohkem inimesi,

\footnotetext{
$29 \quad$ RA, ERA.1108.1.154, 1. 77: Rahvahariduse statistika nr 14.

$30 \quad 1922$ a. üldrahvalugemise andmed. Vihk 1 , Rahva demograafiline koosseis ja korteriolud Eestis = Résultats du recensement de 1922 pour toute la République. Tome I (Tallinn: Riigi Statistika Keskbüroo, 1924), 32-33.

31 Vrd Rahvastikuprobleeme Eestis: II rahvaloenduse tulemusi. Vihk IV = Problèmes de la population: résultats du recensement de 1. III 1934. Vol. IV (Tallinn: Riigi Statistika
} 
kes erinevalt varasemast rahvaloendusest ennast ja oma lapsi sakslastena kirja lasid panna. Lisaks oli 1934. aasta rahvaloenduse järgi 7-14-aastaseid, seega ligikaudu algkooliealisi sakslasi kokku 1642, mis on küll mõnevõrra väiksem kui saksakeelsetes algkoolides õppinud laste arv õppeaastal 1933/34, ent enam-vähem sobivas suurusjärgus. ${ }^{32}$ Ehkki rahvaloendusel üles antud rahvusel ei olnud koolivalikuga mingisugust pistmist, võisid eelnenud aastatel tehtud valikud mõjutada inimesi ka rahvaloendusel teatud andmeid esitama. Näiteks võidi nimetada see rahvus, mis oli kantud viimasesse rahvusmärkega isikutunnistusse, ehkki varasemas võis kirjas olla midagi muud.

Saksakeelsete koolide õpilaste arvu suurenemine tugines seega pigem 1920. aastate jooksul toimunud rahvuskuuluvuse muutustele, mitte niivõrd loomulikule iibele ega mitte-emakeelses koolis õppimiseks antud erilubadele. Samas eelistasid lisaks eestlastele saksakeelseid koole ka teiste vähemusrahvuste esindajad ja proportsionaalselt rahvastiku koosseisuga oli neid saksakeelsetes koolides küllap enamgi kui eestlasi, sest saksakeelseid koole eelistasid sageli ka nende vähemusrahvuste esindajad, kelle emakeelseid koole Eestis ei leidunud. ${ }^{33}$

\section{Avalikkuse ja riigivõimu reaktsioon}

Koolide rahvusliku koosseisu kujunemist mõjutas mingil määral ka asjaolu, et mõned koolijuhatajad võtsid õpilasi vastu ilma eriloata, seega ebaseaduslikult. Kuigi need õpilased võisid olla nii mõne teise vähemusrahvuse esindajad kui ka eestlased, püüdis riik just viimaste ebaseaduslikul moel vähemusrahvuste koolidesse jõudmist takistada. Nagu ilmneb haridusminister Jüri Annussoni 1920. aastal kohalikele koolivalitsustele saadetud ringkirjast, tuli haridusministeeriumil korduvalt selliseid juhtumeid lahendada. Edaspidi pidi ministeerium hakkama ilma eriloata mitte-emakeelsesse kooli

\footnotetext{
Keskbüroo, 1937), 110.

321922 a. üldrahvalugemise andmed. Vihk 1, Rahva demograafiline koosseis ja korteriolud Eestis = Résultats du recensement de 1922 pour toute la République. Tome I (Tallinn: Riigi Statistika Keskbüroo, 1924), 31-32; Rahvastiku koostis ja korteriolud: 1. III 1934 rahvaloenduse andmed. Vihk II = Composition démographique de la population et logements: données du recensement de 1. III 1934. Vol. II (Tallinn: Riigi Statistika Keskbüroo, 1935), 62.

33 Saksa Kultuuromavalitsuse rahvusnimekirjas (RA, ERA.85.1.542) sisalduvast fragmentaarsest saksakeelsete koolide õpilaste kartoteegist ilmneb, et saksa koolides õppis mitmetest eri rahvustest õpilasi. Samuti on saksakeelsete koolide populaarsusest kirjutatud mälestustes, vt nt Dagmar Normet, Avanevad uksed (Tallinn: D. Normet, 2001), 58-59.
} 
õpilasi vastu võtnud koolide pidajaid "seaduslikule vastutusele" võtma. ${ }^{34}$ Kirjast ei järeldu iseenesest, et säärast ebaseaduslikku tegevust oleks ette tulnud väga sageli, küll aga on ilmekas, et ministeerium pidas seda problemaatiliseks ja seega otsustavat reaktsiooni väärivaks nähtuseks.

Et teema oli õhus ka edaspidi, ilmneb mõni aasta hiljem lahvatanud Grassi erakooli skandaalist. Grassi erakooli asutas Tartu Kõrgema LinnaTütarlastekooli saksa keele õpetaja Alfred Grass, kui algselt linna ülalpidamisel olnud õppeasutus 1893. aastal tegevuse lõpetas. Venestusaegsetes oludes oli Grassi kool vene õppekeelega, hiljem aga muudeti saksakeelseks. ${ }^{35}$ Kool tegutses edasi ka pärast Eesti iseseisvumist ega äratanud mitme aasta jooksul suuremat avalikkuse tähelepanu. 1924. aasta kevadel jättis aga haridusministeerium esialgu kinnitamata kooli lópueksamite tulemused, misjärel info ajakirjandusse lekkimisel avastati, et koolis õpib arvukalt mittesakslasi, teiste hulgas eestlasi. Skandaal kogus hoogu sama aasta sügisel, kui muu hulgas levisid süüdistused, et vanemad olid omavoliliselt isikutunnistustel rahvusmärget muutnud ja et ka Grass isiklikult oli valmis seadust rikkudes mittesakslasi kooli vastu võtma. Skandaali paisudes hakati üha enam arutlema koolide õppekeele ja emakeelse hariduse kohustuslikkuse üle, kusjuures levisid algkoolide seaduses sõnastatud põhimõtteid toetavad meeleolud ja "kõva käe" ootus seaduse tõhusamaks jõustamiseks. ${ }^{36}$ Grassi kool ühines osaliselt nende arengute tulemusena 1925. aasta kevadel koos Rathleffi ja Walteri eragümnaasiumidega viimase nime all üheks õppeasutuseks. ${ }^{37}$ Selline lõpptulemus ei vähendanud aga märkimisväärselt üldisemaid diskussioone mitte-emakeelsetes koolides õppimise teemadel.

Olenemata poliitilisest suunitlusest kritiseerisid erinevad ajalehed kogu iseseisvusperioodi vältel "eestlastest" lapsevanemaid ja segaperekondi, kes eelistasid saksakeelseid koole. Sel moel olevat vanemad kaasa aidanud jätkuvale ümberrahvastumisele ning kahjustanud seega eesti rahva ja riigi huve. Selliseid arvamusavaldusi ilmus järjepidevalt nii konkreetseid üksikjuhtumeid avanud artiklites, teemakohastes arvamuslugudes kui ka juhuslike mainimistena mitmetel eri teemadel kirjutatud tekstides. Igapäevasele ajalehelugejale võis kergelt jääda mulje, et saksakeelsete koolide

\footnotetext{
34 Jüri Annusson, "Maakonna- ja linnakoolivalitsustele ja riigikoolide juhatajaile", Kasvatus: Ametlik osa, 2 (3) (1921), 6-7.

35 Allan Liim, "Saksa koolidest Tartus 19. sajandil”, Tartu, baltisakslased ja Saksamaa: Artiklite kogumik, koost Helmut Piirimäe, Claus Sommerhage (Tartu: Tartu Ülikooli Kirjastus, 1998), 140-166 (161-162).

36 Vt nt "Kas A. Grassi saksa eragümnaasiumist saab asja?”, Postimees, 25.07.1924, 5; “"Kadakate” mäss linna koolivalitsuses", Postimees, 28.08.1925, 5; "Kadakasakslus ajab õisi", Kaja, 29.08.1924, 5 .

37 “Kolm saksa eragümnaasiumi ühinevad", Postimees, 22.07.1925, 5.
} 


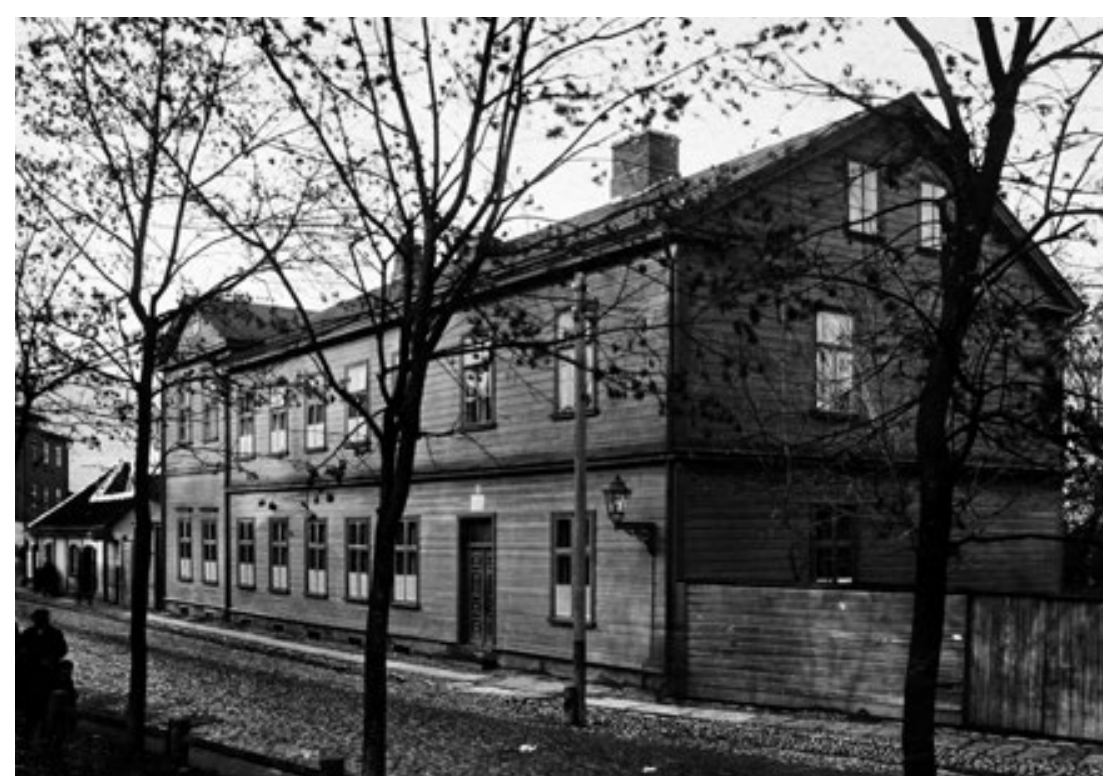

Joonis 6. Alfred Grassi tütarlastekooli hoone Jakobi tänaval, Tartu, enne 1917. RA, EAA.2073.1.279.242

eelistamine on levinud ja ühiskonnaohtlik probleem. Saksakeelsete koolide eelistamine oli ajalehtede järgi tüüpiline "kadakasaksluse" ilming, mis jätkas iseseisvuseelset tõusiklikku oma rahvuse mahasalgamise kommet. ${ }^{38}$ Ajakirjanduse suhtumise taga ei ole keeruline näha ka levinud saksavaenulikkust, mis iroonilisel kombel suunati aga mitte niivõrd sakslaste endi, vaid justkui nendena näida soovivate eestlaste vastu. Mõnel juhul pidasid artiklite autorid vajalikuks selgelt rõhutada, et nende sõnad käivad ainult "kadakasakslaste", aga mitte päris sakslaste ega teiste vähemuste kohta. ${ }^{39}$ Jääb koguni mulje, et ajakirjanikud püüdsid teadlikult kinni hoida kuvandist, mis kujutas Eestit eriti vähemusrahvuste-sõbraliku riigina, ja suunasid oma kriitika pigem ebamäärase rahvuskuuluvusega inimeste kui saksa rahvusgrupi ladviku vastu.

Torkab silma, et ehkki ajakirjanduses käsitleti ka erilubade taotlemist ja sellega seotud probleeme, ei olnud eriload tekstide põhifookuses. Ajakirjanike kriitika oli sihitud eelkõige nende lapsevanemate pihta, kes

\footnotetext{
38 "Kadakasaksluse" problemaatika kohta vt lähemalt Triin Tark, Olev Liivik, "Nationalismus und die "Wacholderdeutschen": Das Thema des Verrats an der Nation in der estnischen Presse der Zwischenkriegszeit”, Nordost-Archiv: Zeitschrift für Regionalgeschichte, 26 (2017), 126-151.

39 Vt nt Lector Novus, “Ajalehti lugedes”, Postimees, 24.08.1924, 4.
} 
väidetavalt enda ja oma laste rahvuskuuluvusega manipuleerisid, selleks et nad soovitud kooli saata: selles valguses käsitleti näiteks isikutunnistuste rahvusmärke muutmist. ${ }^{40}$ Lisaks langesid kriitika alla ühe eestlasest abielupoolega segaperekonnad, kes püüdvat kasvatada lapsi vähemusrahvuste liikmeks ja seetõttu eelistavat saksakeelseid koole, isegi kui kumbki vanem pole sakslane. ${ }^{41}$ Sellise rõhuasetusega poleemika oli kogu ülepaisutatuse juures asjakohane vähemasti sellest aspektist, et ametlikult eestlastest vanemate lapsed tõepoolest ei saanud ulatuslikult saksakeelsetes koolides käia, vaid mõlemad või üks vanematest pidid suutma mingil moel tõestada enda kuulumist saksa rahvusse.

Nii statistilised näitajad kui ka ajakirjanduses levinud poleemika näitavad, et riigiametid ei suutnud koolivalikust ajendatud rahvuskuuluvusega manipuleerimise juhtumeid kuigi edukalt takistada. Samuti näitab Grassi kooli skandaal, et ka juhtumeid, kus koolijuhatajad lubasid õpilasi ebaseaduslikult mitte-emakeelsesse kooli, avastati pigem juhuslikult kui süsteemselt. Ehkki saksakeelsetes koolides óppimiseks väljastatud erilubade arv ei olnud kuigi kõrge, on võimalik, et kohalikud koolivalitsused kaotasid lubade jaga misega seoses aja jooksul üha enam haridusministeeriumi usaldust, kuivõrd 1934. aastal viidi erilubade üle otsustamine ministeeriumi pädevusse. ${ }^{42}$ Võimalusi seaduse nõudest mööda hiilida niisiis leidus, täiel määral mitte-emakeelses koolis õppimist välistada ei suudetud ning riigiametid ja avalikkus olid sellest teadlikud.

Samas ei näita saksakeelsetele koolidele kümne esimese iseseisvusaasta jooksul lisandunud ühtekokku umbes 1000 õpilast, kes ehk tõepoolest ei olnud täielikult saksa keele ja kultuuri taustaga, et oleks olnud levinud nii ulatuslik saksa ja teiste vähemusrahvuste koolide eelistamine eestlastest vanemate poolt, nagu kujutati ajakirjanduses. Lisaks oli vähegi prestiižsemaid saksakeelseid ja teiste vähemusrahvuste koole vähe ja needki asusid enamasti suuremates linnades, mistõttu ei olnud maapiirkondade elanikel sageli võimalik parimagi tahtmise korral oma lapsi vähemusrahvuste koolidesse saata. ${ }^{43}$ Samuti ei toonud mitte-emakeelses koolis õppimine

\footnotetext{
40 Vt nt “"Kadakad” ja "pajuvenelased”", Esmaspäev, o6.02.1928, 1; "Millest maal kõneldakse”, Maa Hääl, 09.10.1933, 8.

${ }_{41}$ Vt nt N., "Neist, kes oma vanemaid ei austa", Sakala, 27.08.1925, 2; K. T., "Kuhu me läheme”, Vaba Maa, 12.12.1931, 4.

42 "Keskkoolide seadus. Antud Riigivanema poolt dekreedina 25. mail 1934", Riigi Teataja, 47, 02.06.1934, 901; "Gümnaasiumide seadus. Antud Riigivanema poolt dekreedina 29. mail 1934", Riigi Teataja, 47, 02.06.1934, 907; "Avalikkude algkoolide seaduse muutmise seadus. Antud Riigivanema poolt dekreedina 7. detsembril 1934", Riigi Teataja, 105, 17.12.1934, 1798-1799.

${ }_{43}$ Vrd “Tab. 3. Õpekeel algkoolides 1921/22 õpeaastal”, Eesti Statistika, 13 (1923), 52-53.
} 
alati kaasa kardetud ümberrahvastumist. ${ }^{44}$ Ka kõik need nüansid pidid haridusametites, -ministeeriumis ning poliitikute seas piisavalt hästi teada olema. Kuna aga küsimus oli ühiskonnas järjepidevalt ja teravalt esil, oli ühtlasi tegemist hõlpsalt politiseeritava ja populismi huvides rakendatava teemaga, mida mitmed poliitilised jõud nii Riigikogus kui ka oma häälekandjate vahendusel ära kasutasid. Eriti kerkis koolidega seotud "kadakluse" teema esile 1930. aastate esimesel poolel, kui ilmnes, et väga lihtne on süüdistada mitmete vabadussõjalaste peresid vähemusrahvuste koolide eelistamises. ${ }^{45}$ Koolieelistuste ja "kadakasaksluse" teema politiseerumine lõi sobiva pinnase rahvuse määramise vabaduse piiramiseks, mis omakorda mõjutas koole ja nende rahvuslikku koosseisu.

Rahvusse kuuluvuse aluste määramise seadus kehtestati 1934. aasta sügisel, natuke rohkem kui pool aastat pärast riigipööret. ${ }^{46}$ Seaduse kehtima hakkamise järel muutus keerulisemaks Saksa Kultuuromavalitsuse rahvusnimekirja astumine ja sel moel laste saksakeelsetesse koolidesse saatmine. Samas ilmneb statistilistest andmetest, et seaduse mõju koolide rahvuslikule koosseisule oli palju laiem. Nagu ilmestab joonis 2, osutus kaalukamaks teguriks asjaolu, et segaperedes, milles isa oli eesti rahvusest, loeti ka lapsed kuuluvaks eesti rahvusse ja nad pidid seega õppima eestikeelsetes koolides. Rahvusse kuuluvuse aluste määramise seadus hakkas kehtima keset õppeaastat, ent selle alusel kooli kohustuslik vahetamine tuli nähtavasti kõne alla alles järgmisest õppeaastast. Nõnda oli 1934/35. õppeaastal toimunud järsk eestlaste osakaalu suurenemine venekeelsetes koolides statistikute selgituse järgi tingitud just uuest seadusest. Ka järgmisel õppeaastal toimunud eestlaste osakaalu vähenemine vene- ja saksakeelsetes koolides oli statistikute hinnangul selle seaduse tagajärg. ${ }^{47}$ Mõistagi tekib siinkohal küsimus, miks samalaadset selget, ehkki ajutist tõusu ei toimunud saksakeelsete koolide puhul. Küllap on siingi oluline tegur venekeelseid koole eelistanud perekondade optanditaust: väljarännanud ja hiljem tagasipöördunud mehed abiellusid Venemaal sageli venelannadega ja nende lapsed õppisid hiljem Eestis venekeelsetes koolides, uue seaduse kehtima hakkamisel tuli need lapsed lugeda aga eestlasteks. Saksa-eesti segaperede

$44 \quad$ Vt nt Toomas Hiio, "Meie võõrad ja meie omad. Saksastumisest, ülikooliharidusest ja karjäärist Heinrich Rosenthalist Feliks Urbanini", Tartu Ülikooli ajaloo küsimusi, 44 (2016), 9-36 (29).

45 Tark, Liivik, "Nationalismus und die "Wacholderdeutschen"“, 143-144.

46 "Rahvusse kuuluvuse aluste määramise seadus. Antud Riigivanema poolt dekreedina 29. oktoobril 1934", Riigi Teataja, 93, 02.11.1934, 1618.

47 A. Lepp, "Alg- ja keskkoolid 1934/35. õ/a", Eesti Statistika, 169 (1935), 601-626 (603); A. Lepp, “Alg- ja keskkoolid 1935/36. õ/a”, Eesti Statistika, 181 (1936), 638-662 (641). 
puhul võrreldavat trendi ei esinenud. Teine võimalik selgitus statistikast ilmnevale erinevusele on asjaolu, et saksakeelseid koole eelistanud lapsevanemad olid oma tahtmise juba varem saavutanud kultuuromavalitsuse rahvusnimekirja kuulumise abil, mis vastavalt uuele seadusele nad riigi silmis automaatselt sakslasteks muutis ja seega võimaldas oma lapsed ka edaspidi saksakeelsetesse koolidesse jätta.

Segaperedele, milles oli eestlasest ema või olid mõlemad vanemad mõnest vähemusrahvusest, jäi endiselt kehtima omavahelise kokkuleppe õigus. Selline olukord ei olnud sugugi mitte kõigile kõrgematele riigiametnikele meelepärane, mistõttu püüti 1939. aasta kevadel läbi suruda seadusemuudatust, millega oleks kohustatud kõiki ühe eestlasest vanemaga perede lapsi õppima eestikeelsetes koolides. See muudatus läbi ei läinud, mis näitab, et küsimuses, kas üldse ning mil määral pidanuks segaperede ja koolide kaudu assimileerimispoliitikat rakendama, üksmeelt ei leidunud. Ka muudatusettepaneku selgituses eeskujuna viidatud Läti praktika kooliseaduse abil segaperede lapsi lätikeelsetesse koolidesse suunata ei osutunud piisavalt veenvaks argumendiks seadusemuudatuse kehtestamiseks. ${ }^{48}$ Nõnda säilis Eestis osal segaperekondadel koolivalikul mõningane vabadus, mida muidu oli märkimisväärselt piiratud.

Põhimõtteliselt võiks pelgalt koolikorraldust silmas pidades oletada, et uue rahvuse määramise seaduse abil suudeti emakeelse hariduse idee lõpuks täiel määral realiseerida. Statistilised andmed näitavad seevastu, et kui ametlikult eestlasteks määratud õpilased suunati edaspidi tõesti suhteliselt efektiivselt eestikeelsetesse koolidesse, siis samal ajal hakkas märgatavalt suurenema ka eestikeelsetes koolides õppinud vähemusrahvusest laste arv, mis ilmneb ka jooniselt 3. Niisiis toimus vähemusrahvuste emakeelses hariduses hoopis mõningane tagasiminek. Nagu allpool lähemalt selgitatakse, ei piirdunud riigi tegevus ainult järelevalvega selle üle, kuidas õpilased eri õppekeeltega koolide vahel jaotuvad, vaid riigipöörde järel võeti lisaks ette mitmeid samme vähemusrahvuste emakeelse hariduse mahu vähendamiseks.

\section{Emakeelse hariduse idee revideerimine}

1922. aasta sügisel saadeti haridusministeeriumist välisministeeriumile lakooniline, arvatavasti rahvusvaheliseks levitamiseks mõeldud teavet sisaldanud ülevaade vähemusrahvuste haridusoludest Eestis. Selles rõhutati deklaratiivsel moel vähemusrahvuste võrdõiguslikkust haridusvaldkonnas

48 RA, ERA.14.17.39: Rahvusse kuuluvuse aluste määramise seadus, 23.05.1939. 
ja esitati napid arvandmed rahvusgrupi suuruse ja koolide arvu seoste kohta. Kogu raporti eesmärk näis olevat tõestada sakslaste hariduslikku eelisseisu, kuna neil oli inimeste arvu kohta enim koole ja klasse, kusjuures saksakeelsete koolide ülalpidamine olevat riigile ka kõige kulukam. ${ }^{49}$ Umbes samal ajal koostati haridusministeeriumis ka teine, mõnevõrra mahukam ülevaade vähemusrahvuste haridusoludest. Seegi raport, olgugi et märkimisväärselt erinevate arvandmetega, püüdis tõestada, et koolide arvu rahvusgrupi suuruse kohta silmas pidades on põhirahvus vähemustest halvemas seisukorras. Lisaks selgub ülevaatest, et haridusministeeriumi silmis andis algkoolide seadus vähemusrahvustele kõigest õiguse omakeelseid koole avada ega kohustanud ministeeriumi ega kohalikke koolivalitsusi millekski. ${ }^{50}$ Ministeeriumi loogika järgi oli vähemusrahvustest õpilasi kohati ühe omakeelse kooli kohta vähem kui oli õpilasi eestikeelsete koolide kohta keskmiselt, mis omakorda tähendas, et vähese õpilaste arvuga koolide ülalpidamine ühe õpilase kohta oli riigi jaoks mõnevõrra kulukam. $\mathrm{Ka}$ ajakirjanduse kaudu levitati arvamust, et vähemusrahvuste koolid ja eriti saksakeelsed õppeasutused eksisteerivad eestikeelsete koolide arvelt. ${ }^{51}$

Vähemusrahvuste õppeasutustest kujunes avalikkuses seega pilt kui eestlaste arvelt parasiteerivatest, eelkõige saksakeelsetest koolidest, mis jättis varju asjaolu, et vähemusrahvustele emakeelse hariduse tagamine sõltus paljuski vähemusgruppide enda aktiivsusest. See tuleb vaid kaudselt välja ülal viidatud haridusministeeriumi ülevaatest, millega see ennast igasugustest kohustustest vabastas. Seega tulenes saksakeelsete koolide suhteliselt suur arv mitte haridusministeeriumi vastutulelikkusest, vaid saksa rahvusgrupi juhtide aktiivsest võitlusest oma õiguste nimel. Mitmete teiste vähemusrahvuste puhul ei ole aga põhjust üldse mingist eelisseisust rääkida. Hästi ilmneb see näiteks soomekeelsete koolide vähesusest seoses (ingeri-)soomlaste endi vähese aktiivsusega omakeelse hariduse eest võitlemisel..$^{52} \mathrm{Ka}$ rootsikeelse gümnaasiumi rajamine Haapsallu oli hoolimata mõningatest riigipoolsetest vastutulekutest näide erainitsiatiivist. ${ }^{53}$

$49 \quad$ RA, ERA.1108.1.203, 1. 41-41p: Statistiline ülevaade vähemusrahvaste haridusoludest Eestis, 12.10.1922; RA, ERA.1108.1.203, 1. 43: Haridusminister Eesti saatkonnale Helsingis, 4.11.1922.

50 RA, ERA.1108.1.154, 1. 134-136: Rahvahariduse statistika nr 20.

51 Tark, Liivik, "Nationalismus und die "Wacholderdeutschen"“, 143.

52 Alenius, “Away with Russian and German Influence!", 359-362.

53 Sven Salin, "Kampen för svenskheten, Svenska Odlingens Vänner och svenska skolor = Võitlus rootsluse eest, Rootsi Hariduse Selts ja rootsi koolid", Hans Pöhl-Estlandssvenskarnas hövding: en biografi över Hans Pöhl (1876-1930), estlandssvenskarnas främste företrädare och ledare = Hans Pöhl - rannarootslaste eestvõitleja: Hans Pöhli (1876-1930), 
Nõnda näib, et vähemusrahvuste emakeelne haridus oli riigivõimu seisukohalt pigem tülikas nähtus, mille jätkuv eksistents oli seotud ühelt poolt ajastu väärtushinnangutega, millest ei olnud niisama lihtne lahti öelda, ja teiselt poolt mõningate vähemusrahvuste esindajate endi aktiivsusega. Iseenesest ei järeldu sellest, et aja jooksul oleks süvenenud poliitikute ja riigiametnike tahe vähemusrahvuste emakeelne haridus täielikult likvideerida ja liikuda täielikult riigikeelse hariduse suunas. Ei andnud sellisteks püüdlusteks alust ka asjaolu, et üldine huvi vähemusrahvuste koolides õppimise vastu püsis läbi terve iseseisvusaja enam-vähem stabiilne ega näidanud erilist langustrendi enne, kui seda hakkas mõjutama 1934. aasta rahvuse määramise seadus. Seegi mõjutas teatavasti esmajoones saksa- ja venekeelseid algkoole, mille õpilaste arv alates 1934/35. õppeaastast selgelt vähenes, samal ajal kui teiste vähemuskeelte koolide puhul võrreldavat muutust ei toimunud ja vahelduva eduga võib mõne rahvuse puhul märgata hoopis õpilaste arvu suurenemist. Niisiis oleks olnud keeruline massilisemat koolide sulgemist või riigikeelsele õppele üleviimist põhjendada õpilaste arvu loomuliku vähenemisega.

Küll aga aitas muutustele kaasa aja jooksul üha enam kinnistunud arusaam, et vähemusrahvustest ópilaste jaoks ei peagi emakeelse hariduse omandamine olema kohustuslik nagu eestlastele. Juba algkoolide seaduse nagu ka põhiseaduse eelnõude lugemisel Asutavas Kogus oli selge, et vähemusrahvustele täiel määral emakeelset haridust tagada ei õnnestu ja seega pole alust kehtestada ka absoluutset kohustust. ${ }^{54}$ Sellised põhimõtteliselt erinevad hoiakud emakeelse hariduse kohustuslikkusest põhi- ja vähemusrahvustele avasid pikemas perspektiivis võimaluse viimaste emakeelset haridust ka aktiivsete sammudega piirama asuda. Alates 1930. aastate algusest riigivõim vaikselt, aga järjekindlalt selle suunas ka liikus. Algust tehti 1931. aastal uue algkoolide seadusega ning 1934. aastal keskkoolide ja gümnaasiumide seadustega ning kõigi nimetatud seaduste parandustega pärast rahvusse kuuluvuse aluste määramise seaduse kehtestamist. Uue algkoolide seadusega võimaldati vähemusrahvustest õpilastel soovi korral ka riigikeelsetes koolides õppida, nagu teises kooliastmes juba aastaid võimalik oli. Muutustega kooliseadustes 1934. aasta sügisel süvendati riigikeelse hariduse kättesaadavust veel enam. ${ }^{55}$

Eesti rootslaste vaimse liidri ja valgustaja elulugu, toim Sven Salin (Stockholm, Tallinn: Svenska Odlingens Vänner, 2010), 117-166 (148-152).

54 Vt nt Asutava Kogu 4. istungjärk, protokoll nr 136, 03.06.1920, vg 729-730.

55 "Algkoolide seadus, 02.06.1931", Riigi Teataja, 46, 09.06.1931, 613; "Keskkoolide seadus", 901; "Gümnaasiumide seadus", 907; "Keskkoolide seaduse muutmise seadus. Antud Riigivanema poolt dekreedina 5. detsembril 1934", Riigi Teataja, 103, 11.12.1934, 
1937. aastal võeti vastu uus põhiseadus, mille järgi võis vähemusrahvuste koolides toimuda õpe edaspidi ka osaliselt riigikeeles. ${ }^{56}$ Tegelikult esines vastav säte esialgses riigivanema esitatud eelnõus kujul, mis eestikeelset õpetust vähemusrahvuste koolides ette ei näinud. Alles arutelude käigus viidi riigikeelne õpe eelnõusse, kusjuures mitmest väljapakutud ettepanekust ühe esitas Saksa Kultuurvalitsuse esimees Wilhelm Wrangell, mis küll põhiseaduse erikomisjonis põhimõttelise muutuse läbi tegi. Kui Wrangelli ettepaneku järgi pidanuks riigikeelt õpetatama "niisuguses ulatuses, et kooli lõpetajad suudaksid täita kodaniku kohuseid", siis muudetud sõnastuses rõhutati mitte riigikeele õpetamist, vaid just nimelt riigikeelset õpet. ${ }^{57}$ Küllap olid kuuldused, et põhiseadusesse vähemusrahvuste koolidele ebasoodsat sätet sisse viima asutakse, jõudnud ka Saksa Kultuuromavalitsusesse, mistõttu püüdsid selle esindajad omapoolse ettepanekuga saavutada enesele kasulikku tulemust, katse ebaõnnestus aga juba eos.

Vähemusrahvuste koolides osaliselt riigikeelse õppe kehtestamise vajadust seostati põhiseaduse arutelude käigus riigikeele positsiooni ja õpilaste keeleoskuse küsimusega. Ühest küljest peeti oluliseks riigikeele esikohale seadmist ainuüksi selle staatusest tulenevalt. Teisest küljest jäid aga kõlama arvamused, et vähemusrahvustest noored ei valda koolist lahkudes piisavalt eesti keelt, et täiel määral ühiskonnaelust osa saada. Samas ei arvatud, et vähemusrahvuste koolid tuleks täielikult riigikeelsele õppele üle viia. ${ }^{58}$ Kokkuvõttes jättis põhiseadus lahtiseks, kas üldse, millises ulatuses ja milliste õppeainetena peaks riigikeelne õpe vähemusrahvuste koolides toimuma. Need küsimused pidanuks lahenduse leidma omaette seadusega, mille vastuvõtmine pidi jääma edaspidiseks.

Järgnevalt püüdiski haridusministeerium korduvalt läbi suruda seaduseelnõu, mis oleks pidanud põhiseaduse vastava punkti ellu viima, ent tulemusteni need katsed ei jõudnud. Arvatavasti oli seejuures märkimisväärne roll vastasseisul, mida eriti tugevalt ilmutas Saksa Kultuuromavalitsus. Esmakordselt kerkis küsimus esile 1937. aasta lõpul, kui vähemusrahvuste koole puudutanud eelnõu haridusministeeriumist valitsusele saadeti.

1749; "Gümnaasiumide seaduse muutmise seadus. Antud Riigivanema poolt dekreedina 5. detsembril 1934", Riigi Teataja, 103, 11.12.1934, 1750; "Avalikkude algkoolide seaduse muutmise seadus", 1798-1799.

56 “Eesti Vabariigi Põhiseadus, 17.08.1937”, Riigi Teataja, 71, 03.09.1937, 1311.

57 RA, ERA.4408.1.92: Rahvuskogu esimese koja põhiseaduse üldkomisjoni koosoleku protokoll $\mathrm{nr}$ 24, 27.05.1937. Arutamisel olnud eelnõude erinevatest sõnastustest annab hea ülevaate nt Rahvuskogu stenograafiliste aruannete lisad: 1937 (Tallinn: Ühiselu, 1938). 58 RA, ERA.4408.1.92: Rahvuskogu esimese koja põhiseaduse üldkomisjoni koosoleku protokoll nr 24, 27.05.1937; RA, ERA.4408.1.83: Bülletään nr 34. Informatsioon Rahvuskogu üldkomisjonide tegevusest. Esimese koja üldkomisjon, 28.05.1937. 
Eelnõu järgi oleks pidanud vähemusrahvuste koolid hakkama mõningaid ained õpetama riigikeeles. Selle peale saatis arengutel silma peal hoidnud Wrangell haridusministrile mureliku kirja, milles väljendas oma vastuseisu kavandatud muudatustele ja kinnitas, et saksakeelsed koolid on ka seni suutnud tagada lõpetajate piisava riigikeele oskuse. ${ }^{59}$ Ehkki eelnõuga järgnevalt aktiivselt edasi ei tegeletud, kerkis küsimus uuesti esile täpselt aasta hiljem. Siis pöördus Wrangell juba otse president Pätsi poole samasuguste seisukohtadega ${ }^{60}$ Kas oli põhjus Wrangelli ja Pätsi isiklikus heas läbisaamises või kõigest seaduseloome aegluses, igal juhul ei jõutudki vähemusrahvuste koolides riigikeelse õppe sisseviimiseni.

\section{Kokkuvõte}

Ei ole üllatav, et riigivõimu silmis oli prioriteet eestikeelse hariduse arendamine ja vähemusrahvustele emakeelse hariduse tagamisega tegeleti kõigist deklaratsioonidest hoolimata pigem vastumeelselt. Samuti pole põhjust üllatavaks pidada emakeelse hariduse idee revideerimist vähemusrahvuste arvel. Asjaolu, et vähemusrahvustest õpilastel võimaldati aja jooksul üha enam riigikeelsetes koolides õppida, oli loogiline asjade käik. Kõik see, mis toimus vähemusrahvuste emakeelse haridusega, oli võrdlemisi hästi kooskõlas ajastule iseloomuliku rahvusriigi ideega ning sarnaseid arenguid võis täheldada mujalgi Ida- ja Kesk-Euroopas. ${ }^{61}$ Samas oli vähemuskeeltes hariduse piiramine vastuoluline samm, pidades silmas, kui jõuliselt pingutasid poliitikud ja haridusametnikud selle nimel, et suunata eestlastest ópilased kohustuslikus korras eestikeelsetesse koolidesse.

Emakeelse hariduse kohustuslikkust eestlastele ei hakatud üle vaatama ka aastaid pärast iseseisvumist, ehkki selleks ajaks võinuks juba olla selge, et vähemusrahvuste koolides õppivate eestlaste arv ei ole kuigi suur,

\footnotetext{
59 "Saksa kultuurvalitsuse kiri Eesti haridusministrile õppekeele kohta vähemusrahvuste koolides, 06.12.1937", Saksa kultuuromavalitsus Eesti Vabariigis 1925-1940: monograafia ja allikad, koost Kaido Laurits (Tallinn: Rahvusarhiiv, 2008), 596-598.

60 "Saksa kultuurvalitsuse esimehe kiri Eesti presidendile seaduseelnõu asjus riigikeelse õpetuse kohta vähemusrahvuste koolides, 06.12.1938”, Saksa kultuuromavalitsus Eesti Vabariigis, 598-599.

61 Vt nt Inesis Feldmanis, "Die innenpolitische Entwicklung Lettlands und die deutschbaltische Minderheit 1918-1940", Die deutsche Volksgruppe in Lettland während der Zwischenkriegszeit und aktuelle Fragen des deutsch-lettischen Verhältnisses, koost Boris Meissner, Dietrich A. Loeber, Detlef Henning (Hamburg: Bibliotheca Baltica, 200o), 58-69; Andrej Tóth, Lukáš Novotný, "On Some Aspects of Political and Legal Background of National Minorities in Czechoslovakia (1918-1938)", Zgodovinski časopis, 1-2 (68) (2014), 216-234; Edward D. Wynot Jr, "The Case of German Schools in Polish Upper Silesia, 1922-1939", The Polish Review, 2 (19) (1974), 47-69.
} 
seda enam, et vähemuste koole terve riigi peale ka kuigi palju ei leidunud. Avalikkuse poleemika oli mitte-emakeelsetes koolides õppinud eestlaste arvu taustal järjepidevalt tugevalt utreeritud, ehkki tõepoolest leidus ka neid ametlikult eestlastest lapsevanemaid, kes eelistasid saksa- või venekeelseid koole. Ühiskonnas levinud hoiakud ei võimaldanud seega hariduspoliitika liberaliseerimist, et neil vähestel vanematel olnuks võimalik ilma rahvuskuuluvusega manipuleerimiseta soovitud eesmärk saavutada. Ühelt poolt oli takistuseks jätkuv, ehkki ebaratsionaalne, ümberrahvastumishirm ühiskonnas, mida ajakirjandus pidevalt tagant õhutas, ent teiselt poolt osutus takistuseks ka emakeelse hariduse idee kui selline. Kui algusest peale ja järjepidevalt olid nii poliitikud kui ka haridusametnikud deklareerinud emakeelses koolis õppimise vajalikkust, siis ei olnud sellest niisama lihtne taganeda.

Ehkki koolide õppekeele teema oli oma poleemilisuse tõttu hõlpsalt politiseeritav, ei kujundanud poliitilised jõud kuigivõrd avalikkuse meeleolusid, vaid pigem kasutasid ära juba levinud vastandlikke seisukohti: ühelt poolt näis avalikkus ülekaalukalt eesti laste õppimist mitte-emakeelsetes koolides taunivat, ent teisalt leidus järjepidevalt lapsevanemaid, kes ei soovinud, et seadused neile kooli õppekeele valiku dikteerivad. Nende hulk oli aga väike ja nad ei suutnud oma sõnumit avalikkuses kuuldavaks teha, mistõttu ei kujutanud nad endast ka sellist jõudu, mis oleks suutnud kaasa tuua hariduspoliitika liberaliseerimise. Samas olid mitte-emakeelseid koole eelistanud vanemad hoolimata väiksearvulisusest piisavalt nähtavad selleks, et 1930. aastate alguse poliitilise kriisi tuules ajendada hoopis senisest märksa piiravamate rahvuse määramise regulatsioonide kehtestamist.

MäRKsõNAD: emakeelne haridus; hariduspoliitika; rahvuspoliitika; sõdadevaheline Eesti

TRIIN TARK on Tartu Ülikooli ajaloo ja arheoloogia instituudi doktorant.*

* Kirjavahetus: Ajaloo ja arheoloogia instituut, Tartu Ülikool, Jakobi 2, 51005, Eesti. E-post: triin.tark@ut.ee 


\section{AвSTRACт: Selective obligation: education in one's mother tongue in interwar Estonia}

The school system in interwar Estonia was based on the idea that every child should receive their primary education in their mother tongue. It was deemed not so much as a right for every ethnic group to have education in their mother tongue, but as an obligation to children and their parents. There are only a few studies on education in one's mother tongue during the interwar period and these do not focus on the long-term impact of this obligation on society. Thus, this article will explain how society adapted to the obligation to learn in one's mother tongue in schools and how this obligation relates to education in one's mother tongue for ethnic minorities, since the initial and main idea of education in one's mother tongue was only to make sure that Estonian children learned in Estonian schools. To answer these questions, legal documentation, newspaper articles, statistics as well as appropriate archival sources are analysed.

The assumption that the priority for state authorities and politicians was the development of Estonian language education was confirmed. The right to education in one's mother tongue for ethnic minorities was rather a symbolic declaration and the state dealt with this question only reluctantly. Schools for ethnic minorities were established and maintained mostly at the initiative of minority elites. The state at the same time considered them too costly and viewed them as existing at the expense of Estonian schools. Against this background, it is natural that the idea of obligatory education in one's mother tongue was revised year by year, but this was only done in relation to the schools of minorities. While the first Primary Schools Act required that all children had to attend schools teaching in their mother tongue with only substantiated exceptions, then later school acts enabled children of minorities to go to Estonian schools. At the same time, the obligation requiring that Estonian children attend Estonian schools remained unchanged.

The obligation for Estonian children to go to Estonian-language schools was not revised even years after the country won its independence, although it was clear that the number of Estonian children in minority schools was small, as was the number of minority schools all over the country. Despite these facts, the polemic and outrage in society regarding the illegal choices made by some parents only grew. Numerous parents who officially identified themselves as Estonian preferred German or Russian schools. In the case of Russian schools, this might be explained by the territories gained 
after the Tartu Peace Treaty and the large number of Estonians who repatriated from Russia in the 1920 and whose children had previously attended Russian schools.

This did not apply to German schools. Some parents used the opportunity to change their official ethnicity or joined the national registry of the German Cultural Self-Government to gain the right to send their children to German schools. The authorities were aware of these mostly successful attempts but did not have many instruments of influence at their disposal to prevent this from happening. At the same time, there was a widespread belief among politicians, which the press also supported, that these attempts should be stopped at all costs. Furthermore, since politicians had for many years already declared the need for obligatory education in one's mother tongue, it would not have been easy to abandon this principle even though there were not many reasons to adhere to it.

The issue of education in one's mother tongue was easily politicised due to its controversial nature. However, politicians did not shape public opinion but rather took advantage of already widespread attitudes. In this regard, there was on the one hand a generally accepted understanding that it was disgraceful for Estonians to prefer minority schools. But on the other hand, there was also a small number of parents who wished to have the right to choose the language of instruction for their children themselves. They were not numerous enough to achieve a more liberal education policy but at the same time they were sufficiently numerous to induce the state to adopt a new law on determination of ethnicity which considerably reduced personal right to decide on one's ethnicity and consequently to choose one's preferred school.

KEYWORDs: education in one's mother tongue; educational policy; national politics; interwar Estonia

Trinn TARK is PhD student at the Institute of History and Archaeology, University of Tartu. ${ }^{*}$

* Correspondence: Institute of History and Archaeology, University of Tartu, Jakobi 2, 51005, Eesti.E-mail: triin.tark@ut.ee 